\title{
Different lengths of treatment with co-trimoxazole for acute uncomplicated urinary tract infections in women
}

\author{
T A M Trienekens, E E Stobberingh, R A G Winkens, A W Houben
}

\begin{abstract}
Study objective-To compare three days' and seven days' treatment with co-trimoxazole in women with acute dysuria, strangury, and urinary frequency or urgency.

Design-Randomised double blind placebo controlled trial.

Setting-General practices in the south east of The Netherlands.

Patients - 327 Non-pregnant female patients aged 12 to 65.

Intervention-161 Women were allocated to three days' treatment (co-trimoxazole $960 \mathrm{mg}$ twice a day), and 166 women were allocated to seven days' treatment (co-trimoxazole $960 \mathrm{mg}$ twice a day).

Main outcome measure-Resolution of symptoms at one, two, and six weeks.

Results-The rates for resolution of symptoms were not significantly different between the two groups. Cumulative rates of recurrence after three days' and seven days' treatment were $31 / 139(22 \%)$ and $23 / 151(15 \%)$ respectively six weeks after entry $(p=0 \cdot 16)$. Adverse effects occurred in a quarter of women given three days' treatment compared with a third of women receiving seven days' treatment $(p=$ $0 \cdot 29$ ). In only two patients did adverse effects necessitate stopping treatment.

Conclusions - Three days of co-trimoxazole seems to be as effective as a seven days' course for treating acute urinary tract infection in non-pregnant women.
\end{abstract}

\section{Introduction}

The prevalence of acute uncomplicated urinary tract infection in women is fairly high at about $50 / 1000 /$ year. ${ }^{2}$ The optimal duration of antibiotic treatment, however, remains a point of discussion. Single dose treatment offers several advantages over the conventional duration, including improved compliance, reduced adverse effects, decreased risk of disturbing bacterial flora and selecting resistant micro-organisms, and lower costs. ${ }^{3+}$ In the past 20 years several studies have suggested that single dose treatment is as effective as the conventional regimens of 10 or 14 days..$^{5-8}$ No study, however, has included enough patients to prevent the type II error. ${ }^{9}$ Freiman et $a l^{10}$ and Fihn and Stamm, ${ }^{11}$ reviewing 71 and 62 clinical studies respectively, concluded that most trials studied too few patients to detect a meaningful difference between the therapeutic regimens. In a recent study with adequate statistical power no symptomatic difference was observed between a single dose and 10 days of cotrimoxazole at three and 13 days and six weeks after the start of treatment. ${ }^{12}$ Adverse effects, however, were twice as common in the group allocated to 10 days of treatment compared with the patients receiving single dose treatments. The authors therefore suggested that an intermediate duration of treatment might be optimal.

We carried out a randomised double blind placebo controlled clinical trial of three days $v$ seven days of cotrimoxazole for treating acute uncomplicated urinary tract infection in women.

\section{Patients and methods}

Non-pregnant female patients aged $12-65$ presenting to their general practitioner with either dysuria, strangury, or urinary frequency or urgency in the past 24 hours were included in the study. Patients were excluded if they had signs and symptoms of acute pyelonephritis, were known diabetics, had known structural abnormalities of the urinary tract, had indwelling catheters, had recently received immunosuppressive drugs, were allergic to trimethoprim, sulphamethoxazole, or co-trimoxazole, or had received antimicrobial treatment within the previous four weeks. Patients with a known urinary tract infection within the past three months were also excluded. Informed consent was obtained from all participants before enrolment.

Patients were assigned in a random and double blind way to receive either three days of co-trimoxazole $960 \mathrm{mg}$ twice a day followed by four days of placebo twice a day (three day regimen) or seven days of cotrimoxazole $960 \mathrm{mg}$ twice a day (seven day regimen). Blinding was achieved with the double dummy technique by using placebo tablets that looked identical to the active tablets (Bactrimel Forte).

Clean voided urine specimens were obtained from all patients for standard quantitative and dip slide culture tests (Orion Diagnostics, Espoo, Finland) and antimicrobial susceptibility tests. For isolating microorganisms standard laboratory methods were used. Bacterial counts were performed by the quantitative surface streak technique with a $0.03 \mathrm{ml}$ standard drop on to $7 \%$ sheep blood agar and MacConkey agar plates. The isolated micro-organisms were identified by standard bacteriological methods that included the analytic profile index (API Montalieu-Vercieu, France) for Enterobacteriaceae. Coagulase negative staphylococci resistant to novobiocin were identified as Staphylococcus saprophyticus. Escherichia coli serotyping (for $\mathrm{O}$ and $\mathrm{K}$ antigens) was carried out with the National Institute for Public Health and Environmental Hygiene (dr Guinée) on the initial and subsequent isolates from most patients whose follow up cultures yielded positive results for $E$ coli. The $\mathrm{O}$ and $\mathrm{K}$ antigens were identified by bacterial agglutination. Urine samples containing more than two species of bacteria were considered to be contaminated and were not included in the analysis. The presence of growth inhibiting factors was detected by using Bacillus subtilis as an indicator strain.

All patients were asked to return to their general 
practitioner one, two, and six weeks after enrolment. On return visits they filled in a questionnaire about relief of symptoms and possible antimicrobial side effects such as headaches, nausea, vomiting, or diarrhoea. In addition, clean voided urine specimens were obtained at each follow up visit and processed in the same way as the initial specimen. Severe side effects were defined as those that needed treatment or that would preclude treatment with co-trimoxazole in the future. From some patients a urine sample was obtained without the questionnaire so the total numbers of patients for whom data on symptoms and bacteriological response were available were different.

Patients were diagnosed as having an urinary tract infection if they presented with acute dysuria, strangury, or urinary frequency or urgency and a bacterial colony count $\geqslant 10^{5}$ colony forming units $/ \mathrm{ml}$. The effectiveness of treatment was based on the short and long term effects of cure, persistence, relapse, and reinfection. ${ }^{11}$ Persistence was defined as the presence of the causative organism in the urine after treatment had stopped and relapse as the absence of the organism at or after the end of treatment but reappearance of the same organism in the two weeks (early relapse) or six weeks (late relapse) after enrolment. Reinfection was defined as the appearance of another infecting organism in the one or two weeks (early reinfection) or six weeks (late reinfection) after enrolment, whereas cure was defined as absence of the causative organism at and during follow up. Failure of treatment was defined as all cases of persistence, relapse, and reinfection as well as those cases of persistence of symptoms or occurrence of adverse drug reactions for which the doctor had to prescribe another drug. Unassessable cases were those for which evaluating bacteriological response was not possible because no follow up cultures were obtained. ${ }^{13}$

Based on data from our pilot study bacteriuria will be eradicated in $90 \%$ of women treated with cotrimoxazole $960 \mathrm{mg}$ twice a day. ${ }^{14}$ We took a $10 \%$ increase in effectiveness of seven days' treatment over three days' to be the minimum; less would not be clinically meaningful because of the lower costs, greater compliance of patients, and fewer adverse effects associated with shorter treatment. Our null hypothesis was that both treatment with three days' and seven days' co-trimoxazole would be successful in $90 \%$ of the patients, and assuming a significance of $p \leqslant 0.05$ and a power of $80 \%$ we calculated that we required 142 patients for each treatment group. ${ }^{1516}$ The comparisons of treatment regimens and differences in

TABLE I-Numbers (percentages) of patients with urinary pathogens before treatment with co-trimoxazole

\begin{tabular}{lcc}
\hline & \multicolumn{2}{c}{ Length of treatment } \\
\cline { 2 - 3 } Urinary pathogen & $\begin{array}{c}\text { Three days } \\
(\mathrm{n}=161)\end{array}$ & $\begin{array}{c}\text { Seven days } \\
(\mathrm{n}=166)\end{array}$ \\
\hline Escherichia coli & $90(56)$ & $83(50)$ \\
Coagulase negative staphylococci & $9(6)$ & $12(7)$ \\
Proteus mirabilis & $6(4)$ & $10(6)$ \\
Other Enterobacteriaceae & $6(4)$ & $6(4)$ \\
Staphylococcus aureus & $48(30)$ & $2(1)$ \\
Negative & & $53(32)$ \\
\hline
\end{tabular}

TABLE II-Response of symptoms in patients with urinary tract infection treated with co-trimoxazole. Figures are numbers (percentages) of patients

\begin{tabular}{|c|c|c|c|c|}
\hline & \multicolumn{2}{|c|}{ Symptoms present } & \multicolumn{2}{|c|}{$\begin{array}{l}\text { Symptoms present and } \\
\text { bacteriologically proved }\end{array}$} \\
\hline & $\begin{array}{l}\text { Three days' } \\
\text { treatment }\end{array}$ & $\begin{array}{l}\text { Seven days' } \\
\text { treatment }\end{array}$ & $\begin{array}{l}\text { Three days' } \\
\text { treatment }\end{array}$ & $\begin{array}{c}\text { Seven days' } \\
\text { treatment }\end{array}$ \\
\hline $\begin{array}{l}\text { Symptoms absent or improved one } \\
\text { week after entry }\end{array}$ & $131 / 142(92)$ & $129 / 145(89)$ & $88 / 97(91)$ & $89 / 97(92)$ \\
\hline $\begin{array}{l}\text { Symptoms absent or improved two } \\
\text { weeks after entry }\end{array}$ & $110 / 121(91)$ & $108 / 121(89)$ & $77 / 83(93)$ & $74 / 81(91)$ \\
\hline Symptoms absent six weeks after entry & $97 / 116(84)$ & $106 / 123(86)$ & $74 / 85(87)$ & $72 / 80(90)$ \\
\hline
\end{tabular}

TABLE III-Cumulative rates of recurrent infections in patients with urinary tract infection treated with co-trimoxazole. Figures are numbers (percentages) of patients

\begin{tabular}{cccc}
\hline & \multicolumn{2}{c}{ Length of treatment } & \\
\cline { 2 - 3 } Time after enrolment (weeks) & Three days & Seven days & p Value \\
\hline 1 & $14 / 145(10)$ & $4 / 152(3)$ & $0 \cdot 02$ \\
2 & $19 / 132(14)$ & $10 / 136(7)$ & $0 \cdot 10$ \\
6 & $31 / 139(22)$ & $23 / 151(15)$ & $0 \cdot 16$ \\
\hline
\end{tabular}

TABLE IV - Numbers of patients with recurrent infection in patients with urinary tract infection treated with co-trimoxazole

\begin{tabular}{lcc}
\hline & \multicolumn{2}{c}{ Length of treatment } \\
\cline { 2 - 3 } Type of failure & Three days & Seven days \\
\hline Persistence & 6 & 4 \\
Early relapse & 3 & 4 \\
Early reinfection & 10 & 2 \\
Late relapse & 5 & 4 \\
Late reinfection & 7 & 9
\end{tabular}

the prevalence of adverse reactions were tested by $\chi^{2}$ analysis.

\section{Results}

Nineteen general practitioners from the south east of The Netherlands participated in the study. From January 1988 to April 1989, 327 women were enrolled in the study: 161 received three days' treatment and 166 seven days' treatment. The mean (SD) ages of both the two groups were $35 \cdot 0(4 \cdot 6)$ and $38 \cdot 4(5 \cdot 4)$ years respectively. Follow up cultures at one, two, and six weeks were obtained from $145(90 \%), 132(82 \%)$, and $139(86 \%)$ patients receiving the short treatment course and $152(92 \%), 136(82 \%)$, and $151(91 \%)$ patients receiving long term treatment respectively.

Table I lists the urinary pathogens isolated. In both treatment groups $E$ coli was the most commonly isolated pathogen followed by coagulase negative staphylococci and Proteus mirabilis. Other Enterobacteriaceae isolated were klebsiella, citrobacter, and enterobacter. No significant differences were found in the rate of isolation of the uropathogens between the different treatment groups. Table II shows that the proportions of women with acute urinary symptoms whose symptoms were relieved after one, two, and six weeks were similar in both groups. The same applied for the patients with bacteriologically proved urinary tract infection.

The cumulative rates of failure were similar in the two treatment groups, with a slightly higher but nonsignificant rate in the patients allocated to three days' treatment (table III). Table IV gives the classification of the failure of treatment in both groups. In the group allocated to three days treatment 12 of the $14 E$ coli isolates from follow up cultures in cases of persistence and relapse were similar in serotype or antibiotic susceptibility, or both, to the original infecting microorganisms; two could not be precisely characterised. The reinfections were caused by $E$ coli (six), coagulase negative staphylococci (five), $P$ mirabilis (four), and pseudomonas (two). The isolated micro-organisms differed in species, serotype, or antibiogram from the orginally infecting strain. E coli (10), klebsiella (one), and coagulase negative staphylococci (one) were isolated from samples from cases of treatment failure in patients allocated to (seven) days' treatment. Eight of the $10 \mathrm{E}$ coli isolates were similar in serotype or antibiotic susceptibility, or both, to the original infecting strain. The remaining two isolates could not be precisely characterised. The klebsiella and coagulase negative staphylococci were both similar in species and antibiogram. $E$ coli and coagulase negative 
staphylococci were isolated five times and Streptococcus faecalis once; they were different in terms of serotype or antibiogram, or both, from the original isolates. Failure of treatment because of resistance to cotrimoxazole occurred in five patients allocated to three days' treatment and in four allocated to 7 days' treatment.

The compliance of the patients was evaluated by using a questionnaire and by testing the urine specimen for the presence of growth inhibiting factors one week after enrolment. Growth inhibiting factors were found in 10 of the 91 specimens in the group allocated to three days' treatment and in 74 of the 101 specimens in the group allocated to seven days' treatment. Unfortunately, first control specimens taken one week after enrolment were not available from all patients.

Subjective adverse effects occurred in 40 patients $(25 \%)$ receiving three days' treatment compared with $51(31 \%)$ receiving seven days' treatment $(\mathrm{p}=0 \cdot 29)$. These included gastrointestinal upset in $22(14 \%)$ and $34(20 \%)$ patients $(\mathrm{p}=0.137)$ and allergic reactions in three $(2 \%)$ and six (4\%) patients (table V). Severe side effects occurred in only two patients (one developed rash, one developed gastrointestinal complaints), both of whom had been allocated to seven days' treatment.

TABLE $\mathrm{v}-$ Adverse effects of treatment with co-trimoxazole. Figures are numbers (percentages) of patients

\begin{tabular}{lcc}
\hline & \multicolumn{2}{c}{ Length of treatment } \\
\cline { 2 - 3 } Effect & $\begin{array}{c}\text { Three days } \\
(\mathbf{n}=161)\end{array}$ & $\begin{array}{c}\text { Seven days } \\
(\mathbf{n}=166)\end{array}$ \\
\hline Nausea & $12(7)$ & $19(11)$ \\
Other gastrointestinal complaints & $10(6)$ & $15(9)$ \\
Vaginal discharge & $2(1)$ & $1(1)$ \\
Rash & $3(2)$ & $6(4)$ \\
Headache & $5(3)$ & $10(6)$ \\
Others & $8(5)$ & $10(31)$ \\
\hline Totals & $40(25)$ & $51(31)$ \\
\hline
\end{tabular}

\section{Discussion}

Our study protocol fulfilled the 12 methodological criteria mentioned by Philbrick $e t a l$ and the recommendations of Fihn and Stamm ${ }^{11}$ to be used in clinical trials of treating uncomplicated urinary tract infections in women. Our results showed no difference in symptomatic response up to six weeks after enrolment between the different treatment regimens either in the group of patients with a bacteriologically proved urinary tract infection or in the group with acute urinary tract symptoms. A similar clinical response was observed in the study of Gossius and Vorland. ${ }^{18}$

The difference in the rate of bacteriological response one week after enrolment might have been due to the presence of growth inhibiting factors in the group allocated to seven days' treatment or to the greater interval after treatment in the group allocated to three days' treatment, enabling early reinfection to occur. Growth inhibiting compounds were found in 74 out of the 101 urine samples from the patients allocated to seven days' treatment. Early reinfection was observed in 10 patients receiving a three days' treatment and in only two patients receiving seven days' treatment. The compliance of the patients allocated to seven days' treatment was $74 \%$ as indicated by the presence of growth inhibiting factors in the urine samples. This is similar to the $75 \%$ compliance with a treatment regimen of twice a day for about 14 weeks found in the study of Cramer et al. ${ }^{19}$

Six weeks after enrolment the cure rates in the groups allocated to three and seven days' treatment were $76 \%$ and $83 \%$ respectively. These proportions were in general lower than those found in other studies. ${ }^{681718}$ The difference might have been due to the fairly short follow up period and the different definitions of cure rate used in other studies. We defined cure rate as relief of initial symptoms plus a sterile urine culture throughout the follow up period. Some investigators used the same definitions but included those patients who were reinfected with a different organism because these patients were cured of the original infection (in our study the so called reinfections) ${ }^{+68} \%$ If we used that definition the cure rates were $90 \%$ and $92 \%$ respectively six weeks after enrolment. These rates are slightly higher than found in the study of Fihn et al ${ }^{12}$ but lower than those described by Gossius and Vorland. ${ }^{18}$

An important issue for the patient is relief of symptoms. Most patients showed relief after one week. After six weeks most patients were still free of symptoms in both treatment groups. In nine out of 31 bacteriological failures in the group allocated to three days' treatment and five out of 23 bacteriological failures in the group allocated to seven days' treatment, however, the infection was also symptomatic. In the other patients the infection was asymptomatic. In the bacteriologically cured group two patients in the group allocated to three days' treatment and three in the group allocated to seven days' treatment still had complaints of urinary tract infection. The cause of these complaints might have been due to the urethral syndrome caused by organisms such as Chlamydia trachomatis. ${ }^{12}$ No significant differences in side effects were observed between treatment regimens.

Major adverse effects-that is, enough to stop treatment-occurred only twice in the patients allocated to seven days' treatment. These occurred less often than they did in other studies. ${ }^{612}$

Based on our results - that is, the similar symptomatic and bacteriological response six weeks after enrolment and the similar occurrence of adverse effects in the two treatment groups in a study that included an adequate follow up period and a large enough sample to allow statistical analysis - we conclude that three days' treatment with co-trimoxazole is as effective as seven days for the treatment of acute urinary tract infection in non-pregnant women. This study, however, was carried out in patients with more or less similar socioeconomic backgrounds and easy accessibility to well organised medical care. Whether these data could be generalised to other populations from lower socioeconomic backgrounds or with other forms of medical care remains to be elucidated.

We thank Drs G H M J Beusmans, W P M Vierhout, W H R Croughs, J R A Y van Rooy, L L J M Keysers, T F W A Krebbers, J Meyers, M Peeters, F W A Vissers, J A G Screever, A J M Screever-Delahaye, J J M Theunissen, F E G Verhaegh, A H Wintjens, P M Heyse, T S T van den Ven, J T Kramers, and J H M Swinkels for their cooperation. The cotrimoxazole and placebos were supplied by Hoffman-La Roche.

1 Kunin CM. Detection, prevention and management of urinary tract infections. 4th ed. Philadelphia: Lea and Febiger, 1987.

2 Baselier P. Acute bacteriële urineweginfecties in de huisartspraktijk [Thesis]. Nijmegen, The Netherlands: University of Nijmegen, 1983.

3 Gleckman RA, Gantz NM, Brown RB. Infections in outpatient practice. Recognition and management. New York: Plenum Medical, 1988.

4 Gleckman RA. Treatment duration for urinary tract infections in adults. Antimicrob Agents Chemother 1987;31:1-5.

5 Greenberg RN, Reilly PM, Luppen KL, Weinandt WJ, Ellington LL, Bollinger MR. Randomized study of single-dose, three-days, and sevendays treatment of cystitis in women. F Infect Dis 1986;153:277-82.

6 Tolkoff-Rubin NE, Weber D, Fang LST, Kelly M, Wilkinson R, Rubin RH Single-dose therapy with trimethoprim-sulfamethoxazole for urinary tract infection in women. Rev Infect Dis 1982;4:444-8.

7 Counts GW, Stamm WE, McKevitt M, Running K, Holmes KK, Turck M. Treatment of cystitis in women with a single dose of trimethoprim-
. sulfamethoxazole. Rev Infect Dis 1982;4:484-90.

8 Buckwold FJ, Ludwig P, Harding GKM, et al. Therapy for acute cystitis in adult women. JAMA 1982;247: 1839-42.

9 Philbrick JT, Bracikowski JP. Single dose antibiotic treatment for uncomplicated urinary tract infections. Arch Intern Med 1985;145:1672-8.

10 Freiman.JA, Chalmers TC, Smith H, Kuebler RR. The importance of beta, the type II error and sample size in the design and interpretation of the randomized control trial. N Engl f Med 1978;299:690-4. 
11 Fihn SD, Stamm WE. Interpretation and comparison of treatment studies for uncomplicated urinary tract infections in women. Rev Infect Dis 1985;7:46878.

12 Fihn SD, Johnson C, Roberts PL, Running K, Stamm WE. Trimethoprimsulfamethoxazole for acute dysuria in women: a single dose or 10-days course. Ann Intern Med 1988;108:350-7.

13 Working Party of the British Society of Antimicrobial Chemotherapy. Clinical evaluation of antibacterial drugs. F Antimicrob Chemother 1989;23(suppl B): $1-39$.

14 Stobberingh EE, Houben AW. Antibioticaresistentie en antibioticagebruik wegens urineweginfecties in 11 Maastrichtse huisartsenpraktijken. Ned Tijdschr Geneeskd 1988;132:1793-7.

$15 \mathrm{McNutt}$ LA, Woolson RF. Sample size for prospective and retrospective studies: the $2 \times 2$ table. Infection Control and Hospital Epidemiology 1988; 9:562-6

16 Pocock SJ. Clinical trials, a practical approach. Chichester: John Wiley, 1987.
17 Shultz HJ, McCaffrey LA, Keys TF, Nobrega FT. Acute cystitis: a prospective study of

18 Gossius G, Vorland L. A randomized comparison of single dose vs. three days and ten days therapy with trimpethoprim-sulfamethoxazole for acute cystitis in women. Scand F Infect Dis 1984;16:373-9.

19 Cramer JA, Mattson RH, Prevey ML, Scheyer RD, Quelette VL. How often is medication taken as prescribed? A novel assessment technique. $\mathcal{J} A M A$ :3273-7.

20 Bailey RR, Blake E. Treatment of uncomplicated urinary tract infections with a single dose of cotrimoxazole. $N Z$ Med $\mathcal{F}$ 1980;92:285-6.

21 Bailey RR, Abbott GD. Treatment of urinary tract infection with a single dose of trimethoprim-sulfamethoxazole. Can Med Assoc f 1978;118:551-2.

(Accepted 23 October 1989)

\section{Health care issues}

The Clinical Encounter: a Guide to the Medical Interview and Case Presentation. J A Billings, J D Stoeckle. (Pp tion. $\mathrm{Jx}+305 ; £ 16.50$ paperback.) Chicago: Xx $+305 ; £ 16.50$ paperback.) Chicago: Year Book Medical Publishers, 1989. Distributed by Wolfe Medica

Health in the Inner Citv. Ed A E While. (Pp viii +180 ; 112.50 paperback.)
Oxford: Heinemann Medical, 1989. ISBN 0-433-00152-6.

NHS Handbook: the National Association of Health Authorities. Ed B Connah, S Lancaster. (Pp xxii +239 £13.95 paperback.) London: Mac-
millan, 1989. ISBN 0-333-48444-4. millan, 1989. ISBN 0-333-48+44-4. Talking with Patients: a Basic Clinical Skill. PR Myerscough. (Pp vil +1 f Oxford University Press, 1989. ISBN 0-19-261769-9.

History of medicine

Brunonianism in Britain and Europe, Medical History. Supplement No 8 W F Bynum, R Porter. (Pp x+104; $£ 15$ in UK and Eire, $£ 19$ overseas, $\$ 30$ USA, including postage and packing.) London: Wellcome Institute for the
History of Medicine, 1988. Obtainable History of Medicine, 1988. Obtainable
from Professional and Scientific from Professional and Scientific
Publications Limited, BMA House, Publications Limited, BMA House,
Tavistock Square; London WC1H Tavistock Square; Lond
9JR. ISBN 0-85484-075-3.

Dartford's Capital River: Paddle Steamers, Personalities and Smallpox
Boats. J Burne. (Pp 120; figs; 115.95 .) Buckingham: Barracuda Books, 1989. ISBN 0-86023-454-1.

Health for Sale: Quackery in England 1660-1850. R Porter. (Pp xi +280 £19.95.) Manchester: Manchester University Press, 1989. ISBN 0-71901903-6.

Health, Happiness, and Security: the Creation of the National Health Service. Creation of the National Health Service.
F Honigsbaum. (Pp xv $+286 ; 135$. F Honigsbaum. (Pp xv +286 ; 335 .)
London: Routledge, 1989. ISBN London: Rou

A History of Vascular Surgery. SG Friedman. (Pp xi+212; figs; $\$ 27.50$.) New York: Futura, 1989. ISBN 0-87993-341-0.

Hormonal Regulation of the Menstrual Cycle: the Evolution of Concepts. JC Gruhn, R R Kazer. (Pp xviii +237; figs; \$35.) New York: Plenum Medical, 1989. ISBN 0-306-43077-0.

Medical Revolution in Minnesota: a History of the University of Minnesota Medical School. L G Wilson. (Pp xi+ 612; figs; $\$ 55$, plus postage $\$ 2.50$ in USA, $\$ 3.50$ all other countries.) 1989 Available from Midewiwin Press, 797 Goodrich Avenue, Saint Paul,
Minnesota 55105, USA. ISBN Minnesota 55105,

A Model of Its Kind. Vol 1. "A Centennial History of Medicine and Johns Hopkins." A M Harvey, GH Brieger, S L Abrams, V A McKusick. (Pp xi+372; figs; f19.) Baltimore: Johns Hopkins University Press, 1989. ISBN 0-8018-3794-4.

A Model of Its Kind. Vol 2. "A Pictorial History of Medicine at Johns Hopkins." A M Harvey, G H Brieger,
SL Abrams, JM Fishbein, VA
McKusick. (Pp vii +172; figs; £13.) Baltimore: Johns Hopkins Universit Press, 1989. ISBN 0-8018-3816-9.

The Works of William Harvey. Translated by R Willis. (Pp 28+xxxi+624; £31.45.) Philadelphia: University of Pennsylvania Press, 1989. ISBN 0-8122-8166-7.

\section{Human reproduction}

Brain Opioid Svstems in Reproduction. Ed RG Dyer, R J Bicknell. (Pp xiv +365 ; figs; $\mathcal{E}+5$.) Oxford: Oxford University Press, 1989. ISBN 0-19857694-3.

Life Before Birth: Reflections on th Embryo Debate. R Edwards. (Pp xii 186; figs; 1 14.95.) London: Hutchinson, 1989. ISBN 0-09-168150-2.

\section{Immunology}

The Immune System: Evolutionary Principles Guide Our Understanding of This'Complex Biological Defense System. R E Langman. (Pp xlvi +209 figs; \$49.95.) San Diego: Academic Press, 1989. Distributed by Harcourt
Brace Jovanovich. ISBN $0-12$ 436585-X.

Immunology: a Foundation Text. B Davey. (Pp 168; figs; £10.95 paperback.) Milton Keynes: Open 09258-6.

In Focus. "Antigen-Presenting Cells." JM Austyn. Series editors D Rick wood, D Male. (Pp 79; figs; 26.50 paperback.) Oxford: IRL Press at Oxford University Press, 1989. ISBN 0-19-963005-4.

Infection

Anaerobic Infections in Humans. Ed SM Finegold, W L George. (Pp xxiv + 851; figs; \$149.) San Diego: Academic Press, 1989. Distributed by Harcourt Press, 1989. Distributed by Harcour
Brace Jovanovich. ISBN 0-12 Brace J
256745-5.

Recent Advances in Infection. No 3. Ed DS Reeves, A M Geddes. ( $P p$ viii 252; figs; £45.) Edinburgh: Churchill Livingstone, 1989 . ISBN $0-443$ 03406-0.

\section{Neurology}

Central Nervous System: Clinical Algorithms. British Medical fournal. (Pp viii +45 ; $£ 6.95$, overseas $£ 8$ paperback, including postage, airmail overseas. BMA members $£ 6.45$, oversea £7.50 including postage.) London: British Medical fournal, 1989. In North America available from the American College of Physicians, PO Box 7777-R-0270, Philadelphia,
19175, USA. ISBN 0-7279-0256-3.

Handbook of Neurological Investigations in Children. J B P Stephenson, M D King. (Pp 14+244; figs; £25 paperback.) London: Wright, 1989. Disback.) London: Wright, 1989. Dis-
tributed by Butterworth Scientific. tributed by Butterw

\section{Pathology}

Pathology of Human Disease. J B Walter. (Pp xiv +1013 ; figs; $£ 28.33$ paperback.) Philadelphia: Lea and Febiger, 1989. ISBN 0-8121-1151-6.

\section{Perinatal care}

Contemporary Issues in Fetal and Neonatal Medicine. 5. "Perinatal Brain Lesions.” Ed K E Pape, J S Wigglesworth. Series editors $N$ N Finer, $M$ L Chiswick. (Pp viii +279 ; figs; $£ 35$.) Chiswick. (Pp viii +279 ; figs; 335 .)
Boston: Blackwell Scientific, 1989. Boston: Blackwell
ISBN 0-86542-028-9.

\section{Pharmacology-clinical}

Human Drug Kinetics: a Course of Simulated Experiments. L Saunders, D Ingram, S H D Jackson. (Pp xxii + 262; figs; £100 for book and associated software.) Oxford: IRL Press at Oxford University Press, 1989. ISBN 0-19-963039-9.

\section{Psychology}

One to One: Experiences of Psychotherapy. R Dinnage. (Pp 218; 44.99 paperback.) London: Penguin, 1989. ISBN 0-14-022816-0.

\section{Radiology}

Doppler Echocardiography: an Illustrated Clinical Guide. P Wilde. ( $\mathrm{Pp}$ ix +153 ; figs; £29.95.) Edinburgh:
Churchill Livingstone, 1989. ISBN 0-443-03481-8.

Handbook of Cardiovascular and Interventional Radiologic Procedures. $\mathrm{K}$ Kandarpa. (Pp xviii + 254; figs; £16.95 paperback.) Boston: Little,
1989. ISBN 0-316-48255-2.

Imaging of Sports Injuries. A Williams, R Evans, P D Shirley. (Pp viii + 182; figs; £35.) London: Baillière Tindall, 1989. Distributed by Harcourt Brace Jovanovich. ISBN 0-7020-1368-4.

Introduction of Neuroimaging. W W Orrison, Jr. (Pp ix + 395; figs; £43.50.) Boston: Little, Brown, 1989. Distributed by Churchill Livingstone. ISBN 0-316-66492-8.

\section{Respiratory medicine}

Living with Asthma and Hay Fever. J Donaldson. (Pp xiii +226; figs; $\$ 4.99$ paperback.) London: Penguin, 1989. ISBN 0-14-010875-0.

Lung biology in Health and Disease. Vol 42. "Heart-Lung Interactions in Health and Disease."'Ed S M Scharf, S $S$ Cassidy. Executive editor C Lenfant. (Pp xxv + 1135; figs; \$210.) New York: Dekker, 1989. ISBN 0-8247-7986-X.

\section{Rheumatology}

Sjogren's Syndrome: the Sneaky "Arthritis". S Dauphin. (Pp vi+158; figs; £6.95 paperback.) Florida: Pixel Press, 1989. ISBN 0-9620354-0-8.

\section{Sexual disorders}

It's Up to You: Overcoming Erection Problems. W Williams. (Pp $\mathbf{x}+$ 165; figs; $£ 4.99$ paperback.) Wellingborough: Thersc

\section{Sports medicine}

Contemporary Exercise and Sports Medicine Series. Vol 2. "Drugs and the Athlete. G I Wadler, B Hainline. Editor-in-chief A J Ryan. (Pp xxii +

353; £33.) Philadelphia: Davis, 1989. ISBN 0-8036-9008-8.

Sports Medicine, Exercise and Fitness: a Guide for Evervone. CK Giam, $\mathrm{K} \mathrm{C}$ Teh. (Pp xviii +246; figs; $\$ 9.50$ paperback.) Singapore: PG Publishing Pte, 1989. ISBN 981-3096-17-9.

Sports Medicine of the Lower Extremity. Ed S I Subotnick. (Pp xv+683; figs £49.50.) New York: Churchill Livingstone, 1989. ISBN 0-443-08560-9.

\section{Surgery}

Body Sculpturing by Lipoplasty. Y-G Illouz, Y T de Villers. (Pp xvi +482 figs; £140.) Edinburgh: Churchil Livingstone, 1989. ISBN 0-44303833-3. Complications in Surgery Series.
"Complications in the Surgical "Complications in the Surgical
Management of Gynaecological and Obstetrical Malignancy." J M and Obstetrical Malignancy." J M Monaghan. Series editor J A R Smith.
(Pp ix + 170; figs; $\$ 30$.) London: BailPp ix $+170 ;$ figs; $£ 30$. London: Bail-
lière Tindall, 1989. Distributed by Harcourt Brace Jovanovich. ISBN 07020-1358-7.

Controversies in General Surgery. Ed T G Allen-Mersh. (Pp vi $+122 ; £ 10$ paperback.) London: Arnold, 1989. paperback.) London:

Decision Making in Surgery of the Chest. 